\title{
Novel Cell and Gene Therapies for HIV
}

\author{
James A. Hoxie ${ }^{1}$ and Carl H. June ${ }^{2}$ \\ ${ }^{1}$ Division of Hematology/Oncology, Department of Medicine, University of Pennsylvania School of Medicine, \\ Philadelphia, Pennsylvania 19104 \\ ${ }^{2}$ Abramson Family Cancer Research Institute and Department of Pathology and Laboratory Medicine, \\ University of Pennsylvania School of Medicine, Philadelphia, Pennsylvania 19104 \\ Correspondence: hoxie@mail.med.upenn.edu
}

Highly active antiretroviral therapy dramatically improves survival in HIV-infected patients. However, persistence of HIV in reservoirs has necessitated lifelong treatment that can be complicated by cumulative toxicities, incomplete immune restoration, and the emergence of drug-resistant escape mutants. Cell and gene therapies offer the promise of preventing progressive HIV infection by interfering with HIV replication in the absence of chronic antiviral therapy. Individuals homozygous for a deletion in the CCR5 gene (CCR5 $\Delta 32)$ are largely resistant to infection from R5-topic HIV-1 strains, which are most commonly transmitted. A recent report that an HIV-infected patient with relapsed acute myelogenous leukemia was effectively cured from HIV infection after transplantation of hematopoietic stem/progenitor cells (HSC) from a CCR5 332 homozygous donor has generated renewed interest in developing treatment strategies that target viral reservoirs and generate HIV resistance in a patient's own cells. Although the development of cell-based and gene transfer therapies has been slow, progress in a number of areas is evident. Advances in the fields of gene-targeting strategies, T-cell-based approaches, and HSCs have been encouraging, and a series of ongoing and planned trials to establish proof of concept for strategies that could lead to successful cell and gene therapies for HIV are under way. The eventual goal of these studies is to eliminate latent viral reservoirs and the need for lifelong antiretroviral therapy.

In the era of highly active antiretroviral therapy (HAART), HIV replication can be suppressed to low or undetectable levels (Kaufmann et al. 2000; Maartens et al. 2007; Kitahata et al. 2009) with a corresponding but variable increase in CD4 T-cell counts (Valdez et al. 2002; Moore et al. 2005; Geng and Deeks 2009). Survival has improved dramatically, and HAART has turned HIV infection into a chronic, manageable illness. However, survival remains reduced by at least 10 years compared with the general population, and there are long-term complications (Lewden et al. 2005; Lohse et al. 2007) including accelerated cardiovascular disease, liver and renal failure, neurocognitive dysfunction, and HIV-associated malignancies (Cheung et al. 2005; Lekakis and Ikonomidis 2010; Nunez 2010; Xia et al. 2011). Ongoing immune activation and inflammation can occur and may contribute to

Editors: Frederic D. Bushman, Gary J. Nabel, and Ronald Swanstrom

Additional Perspectives on HIV available at www.perspectivesinmedicine.org

Copyright (C) 2012 Cold Spring Harbor Laboratory Press; all rights reserved; doi: 10.1101/cshperspect.a007179

Cite this article as Cold Spring Harb Perspect Med 2012;2:a007179 
increased morbidity and mortality (Giorgi et al. 1999; Rodger et al. 2009). Many patients, particularly those who began HAART in the setting of advanced immunodeficiency, do not achieve complete CD4 reconstitution ( $\geq 500$ cells/ $\mathrm{mm}^{3}$ ) (Valdez et al. 2002; Kelley et al. 2009), which has been linked to increased morbidity (Lewden et al. 2007; Baker et al. 2008). Moreover, even when viral replication is suppressed for many years, replicating HIV typically reappears in plasma once HAART is discontinued, indicating that patients are not cured and that long-lived viral reservoirs persist (Chun and Fauci 1999; Blankson et al. 2002). Given the limitations and the potential complications of HAART, there has been renewed interest in novel approaches to control or preferably cure HIV infection (Richman et al. 2009).

With advances in understanding the molecular basis for HIV replication and mechanisms for host control, a number of investigators are focusing on cell-based and gene therapy either as stand-alone approaches or as adjuvants to pharmacological drug regimens. There have been several excellent reviews of this topic (Poluri et al. 2003; Strayer et al. 2005; Edelstein et al. 2007; Rossi et al. 2007). These approaches have potential advantages compared to conventional drugs. In particular, the self-renewing properties of cell and genetic strategies at least in principal can obviate the need for lifelong antiretroviral medications. As will be discussed, cell-based approaches involving hematopoietic stem cell transplantation have the potential to be curative (Hütter et al. 2009; Allers et al. 2010; Deeks and McCune 2010). This review will consider novel therapies that focus on modifying host cells to resist HIV infection with approaches directed at viral or cellular targets. One general consideration is that although nucleic acid-based antivirals can be designed to have high specificity for HIV-1 targets at the gene, RNA, or protein level, as with pharmacologic approaches, viral escape is a major concern. In contrast, cellular targets are far less prone to mutational escape, although with the exception of CCR5, the side effects of down-regulating cellular targets for the long term are unknown.

\section{HISTORY}

Cell and gene therapy strategies have been proposed from the earliest days of the HIV epidemic. Friedmann and Anderson have reviewed the conception and early history of gene transfer therapy (Friedmann and Roblin 1972; Anderson 1984; Friedmann 1992). Baltimore first proposed a gene therapy approach for treating HIV/AIDS, in which a retrovirus could be engineered to antagonize HIV by expressing dominant negative RNA or protein inhibitors (Baltimore 1988).

\section{Allogeneic and Xenogeneic Transplantation}

Xenotransplantation was proposed as a cellbased therapy, with the rationale that HIV-1infected humans could be reconstituted with nonhuman primate bone marrow, an approach that would take advantage of the intrinsic resistance of nonhuman species to infection with HIV-1. In 1995, a 38-yr-old patient infected with HIV for more than 15 years underwent a controversial experiment following approval by the U.S. Food and Drug Administration. His bone marrow was suppressed by sublethal doses of radiation and chemotherapeutic drugs, after which he received an infusion of bone marrow cells from a baboon. This experiment occurred before the advent of HAART therapy, at a time when the standard treatment approaches were failing to control HIV, and the AIDS activist community was increasingly convinced that radical approaches should be explored. The patient survived and improved for reasons that are unclear, as the baboon cells failed to engraft and were not detectable in his bone marrow beyond the first month posttransplant (Michaels et al. 2004).

Allogeneic and syngeneic (twin) hematopoietic stem cell transplantation (HSCT) were proposed as a treatment for AIDS, based on the positive experiences with allogeneic HSCT in children with severe combined immunodeficiency (Cavazzana-Calvo and Fischer 2007). Patients with HIV/AIDS-associated malignancies for whom HSCT was standard therapy provided an opportunity to determine the regenerative potential of bone marrow and 
mature lymphocytes in the setting of HIV infection. The first report of allogeneic HSCT described two men with AIDS and Kaposi's sarcoma who were given infusions of partially compatible bone marrow from uninfected family donors (Hassett et al. 1983). No clinical benefit occurred, and engraftment of the donor bone marrow was brief, probably because no conditioning regimen was given to the patients. In retrospect, it was not realized at that time that even though AIDS patients have severe immunosuppression, they are still able to mount potent rejection responses to organ and bone marrow grafts. Lane and colleagues conducted the first study using infusion of bone marrow from a healthy identical twin to a patient with AIDS. The patient was given a single infusion of bone marrow without conditioning, followed by repeated infusions of syngeneic peripheral blood lymphocytes from the donor (Lane et al. 1984). Transient clinical benefit was observed with increased CD4 counts that peaked three months after stem cell infusion. These early experiments were conducted in the pre-HAART days in the presence of high levels HIV viremia, and the results may have been more durable with long-term immune reconstitution had effective antiretroviral therapy been available. Consistent with this notion, Holland and coworkers reported the case of a patient with HIV and lymphoma who received an allogeneic HSCT with concomitant zidovudine therapy. The patient engrafted with donor marrow, but died from progressive lymphoma 47 days after HSCT. An autopsy revealed no evidence for residual HIV-1 by culture or polymerase chain reaction (PCR) of numerous tissues, suggesting that myeloablative chemoradiotherapy combined with antiretroviral therapy had a substantial impact on latent viral reservoirs in host cells (Holland et al. 1989).

\section{PROTEIN-BASED INHIBITORS}

A number of criteria have been proposed for developing genetic inhibitors of HIV for human clinical trials, including (1) potency of inhibition, (2) lack of immunogenicity, (3) lack of toxicity, (4) the stage in the viral life cycle that they target, and (5) their potential for selecting resistant viruses (Dropulic and June 2006). Mathematical modeling has predicted that postintegration inhibitors lead to the persistence of cells carrying an integrated provirus, resulting in an accumulation of HIV-1-infected cells that could ultimately counteract their antiviral effect. In contrast, inhibitors that act before integration, even those with lower potency, are predicted to exert a systemic antiviral effect with the expansion of transduced cells capable of resisting HIV infection (von Laer et al. 2006).

Protein-based inhibitors can be directed toward cellular or viral targets and have included dominant negative inhibitors, intrabodies, intrakines, fusion inhibitors, and zinc finger nucleases (ZFNs). Each type of protein inhibitor is described in detail below. These inhibitors are typically expressed from a viral vector long terminal repeat (LTR), but in several instances are produced from strong constitutive promoters inserted within the bodies of the viral vectors. Strictly speaking, ZFNs are protein-based inhibitors that have a fundamentally different mechanism than the other inhibitors in this class, and so are discussed in a separate section.

\section{Dominant Negative Inhibitory Proteins}

The first protein used in a gene therapy trial for treating HIV infection was a mutant form of the HIV Rev protein called M10 (Woffendin et al. 1996). Rev M10 is believed to work by blocking the export of singly spliced and unspliced HIV RNA from the nucleus to the cytoplasm thereby preventing viral assembly and subsequent transmission (Malim et al. 1992). This mutant protein remains one of the most potent inhibitors of HIV replication and has been evaluated in human clinical trials (Ranga et al. 1998; Morgan et al. 2005; Podsakoff et al. 2005). Although there was no long-term benefit, a modest survival advantage of M10-expressing CD4 cells was observed.

\section{Intrabodies and Intrakines}

The expression of intracellular antibodies (termed "intrabodies"), typically as single-chain Fv fragments that target viral or cellular proteins, 
and chemokines (termed "intrakines") have also proven to be very potent inhibitors of HIV replication in vitro (Yang et al. 1997; Schroers et al. 2002; Poluri et al. 2003; Lobato and Rabbitts 2004; Lo and Marasco 2008; Zhang et al. 2009). These proteins bind to viral or cellular target proteins leading to their intracellular degradation. Notable cellular targets for this approach have included the HIV coreceptors CCR5 and CXCR4 (Yang et al. 1997; Schroers et al. 2002; Zhang et al. 2009).

\section{Fusion Inhibitors}

von Laer and colleagues developed a novel protein-based fusion inhibitor, termed C46, which binds to HIV gp41 at the cell surface and blocks viral entry (Hildinger et al. 2001; Egelhofer et al. 2004; Perez et al. 2005). C46 is comprised of amino acids from the second heptad repeat of gp41. As with other protein-based inhibitors, it can be expressed constitutively by retroviral vectors and applied to a gene therapy setting. A membrane-anchored form of C46 (maC46) was shown to confer HIV resistance to hematopoietic stem cells in nonhuman primates (Trobridge et al. 2009). In a comparative study, the maC46 fusion inhibitor was compared to an HIV-1 tat/rev-specific small hairpin (sh) RNA (Lee et al. 2002) and an RNA antisense gene specific for the HIV-1 envelope glycoprotein (Dropulic et al. 1996). Notably, maC46 proved to be the most potent in conferring a selection advantage to transduced cells following HIV-1 inoculation in vitro and in humanized mice in vivo (Kimpel et al. 2010). The maC46 transgene was tested in a phase I trial in 10 patients with late-stage HIV infection (van Lunzen et al. 2007). The infusions of transduced $\mathrm{T}$ cells were well tolerated, and a significant albeit transient increase of CD4 counts was observed after infusion.

\section{Inhibitors of Viral Restriction Factor, TRIM5 $\alpha$}

An early event in the viral life cycle that is well suited to protein-based inhibition is uncoating of the viral capsid following entry, which is highly restricted for HIV-1 in rhesus macaques by the host protein tripartite motif (TRIM) $5-\alpha$ (Stremlau et al. 2004; Nisole et al. 2005; Malin and Bieniasz 2011). Under permissive conditions the HIV and SIV capsid proteins have evolved to escape binding by TRIM5- $\alpha$, which otherwise binds and leads to degradation of the capsid and a failure of reverse transcription. It has been shown in vitro that in human cells expressing either TRIM5- $\alpha$ from a nonpermissive primate species or a human TRIM5- $\alpha$ that was rendered competent for binding to the HIV capsid, these proteins act in a dominant negative manner to inhibit replication (Yap et al. 2005; Stremlau et al. 2006). These approaches represent promising interventions for future protein-based gene therapy.

Although protein-based approaches can have potent antiviral effects in vitro, a principal limitation is not only the need to maintain sufficient levels of expression from the vector, but to avoid immunogenicity in vivo, as immune responses could confound persisting antiviral activity. Thus, for protein inhibitors that are advanced to clinical trials both their potency and immunogenicity will need to be assessed.

\section{NUCLEIC ACID-BASED INHIBITORS}

A number of RNA-based approaches, including antisense RNAs, aptamers, decoys, ribozymes, and si/shRNAs have been described. An advantage of these inhibitors is that in contrast to protein-based inhibitors, they do not elicit adaptive T-cell responses and are unlikely to be immunogenic. However, RNA approaches can potentially have off-target toxicity because of activation of innate immune responses and competition with endogenous RNA functions (Lares et al. 2010).

\section{Antisense RNA}

Short and long antisense RNA transgenes that pair with HIV transcripts to form duplexes that are nonfunctional have been effective in blocking HIV replication in hematopoietic cells. The first demonstration of this principle came from studies using adeno-associated virus vectors to deliver a short anti-U5 region antisense 
RNA (Chatterjee et al. 1992). More recently, Levine and coworkers infused patients with autologous CD4 $\mathrm{T}$ cells that were genetically modified by a conditionally replicating lentiviral vector expressing a long antisense RNA to the HIV envelope mRNA (Levine et al. 2006). In a follow-up study (clinicaltrials.gov NCT00295477), Tebas and coworkers showed a decrease in viral load in the majority $(88 \%$ $[7 / 8]$ ) of these patients after antiretroviral therapy was discontinued, with one patient maintaining undetectable HIV RNA for 104 days (Tebas et al. 2010). Although the mechanism by which these antisense transcripts inhibited HIV replication is not clear, it could have triggered extensive adenosine deamination of the $\mathrm{HIV} /$ antisense duplex, resulting in nuclear retention of transcripts or the generation of multiple viral disabling mutations ( $\mathrm{Lu}$ et al. 2004). A further analysis of transduced cells from patients in this trial using 454 pyrosequencing showed no evidence for abnormal expansion of cells because of vector-mediated insertional activation of proto-oncogenes, suggesting that no adverse events were apparent at the molecular level (Wang et al. 2009).

\section{Aptamers}

RNA aptamers are RNA molecules with structural features that facilitate high-affinity interactions with targeted ligands. They are amenable to rapid selection in vitro and can be designed to bind to virtually any protein of choice (Nimjee et al. 2005). There are now a number of highly effective aptamers available for testing in gene therapy settings (Symensma et al. 1996; Joshi et al. 2003; Held et al. 2006, 2007; Kissel et al. 2007), although to date none have been tested in clinical trials for HIV infection.

\section{RNA Decoys}

The HIV Tat protein binds to a structure on the $5^{\prime}$ UTR of mRNAs termed the TAR motif, and is required for efficient transcription (Arya et al. 1985; Sodroski et al. 1985). Short RNA oligonucleotides corresponding to the TAR sequence, termed TAR decoys, bind to Tat and block its interaction with the authentic TAR region to inhibit HIV gene expression and replication (Lisziewicz et al. 1993; Bohjanen et al. 1997). RNA decoys have also been developed to prevent Rev from binding to the Rev response element (RRE), which is required to transport unspliced and singly spliced mRNAs from the nucleus (Lee et al. 1994). A clinical trial to evaluate the safety and feasibility of an RRE decoy was conducted using bone marrow from four HIV-1-infected pediatric subjects (Kohn et al. 1999). The approach was safe; however, expression of the RNA decoy was likely insufficient for antiviral effects to be seen.

\section{Ribozymes}

Ribozymes are antisense RNAs that not only bind but enzymatically cleave targeted mRNAs. The first demonstration that ribozymes were effective in inhibiting HIV replication was published in 1990 (Sarver et al. 1990). Since then, many ribozyme-based antivirals have been developed, and some have been evaluated in clinical trials including those targeting HIV genes tat and rev, and the U5 region of the viral LTR. Ribozymes in these trials were either expressed from the retroviral LTRs as long, capped, polyadenylated transcripts from the retroviral LTR promoter (Bauer et al. 1997; Ngok et al. 2004), or as a discrete, chimeric Pol III tRNA-ribozyme transcript (Leavitt et al. 1994; Li et al. 2005). Four of these trials involved retroviral vector delivery of decoy or ribozyme genes into autologous hematopoietic progenitor cells isolated from $\mathrm{HIV}$-1-infected individuals (Kohn et al. 1999; Amado et al. 2004; Mitsuyasu et al. 2009; DiGiusto et al. 2010). Following retroviral transduction, cells were reinfused either in the absence of bone marrow conditioning, or in one case with bone marrow conditioning to treat an AIDSrelated lymphoma (DiGiusto et al. 2010). Although these trials showed that ribozymes and decoys could be safely introduced into mobilized stem cells or peripheral blood mononuclear cell cultures (PBMCs) and reinfused in patients, no significant anti-HIV effects were observed. However, in a recent phase II clinical 
trial, Mitsuyasu et al. (2009) showed that an anti-tat ribozyme could be safely introduced in autologous stem cells from a gammaretroviral vector. This vector (termed OZ1) expressed a hammerhead ribozyme that targeted the overlapping reading frames of the viral $\mathrm{vpr}$ and tat genes in unspliced and spliced viral transcripts, respectively. Although no significant differences were observed in the viral load between OZ1-treated and placebo groups at the time of study's primary end point at 12 months, they observed a significantly lower viral load at later time points, and OZ1-treated patients had higher CD4 cell numbers at all time points. This study is notable because it is the first randomized, double-blinded phase II clinical trial for HIV-1 infected patients to test gene-modified HSC, and showed the feasibility of conducting complex cell and gene transfer trials that will likely be used in future protocols to eradicate HIV infection.

\section{RNA Interference}

RNA interference (RNAi) is a regulatory mechanism of most eukaryotic cells that uses small double-stranded RNA (dsRNA) molecules as triggers to direct homology-dependent control of gene activity (Hannon and Rossi 2004). Known as small interfering RNAs (siRNA) these 21- to 22-bp-long dsRNA molecules have characteristic two-nucleotide $3^{\prime}$ overhangs that allows them to be recognized by the enzymatic machinery of RNAi leading to homologydependent degradation of the target mRNA. To date, preclinical studies indicate that this is the most potent RNA-based inhibitory mechanism available for therapeutic application. Virtually all of the HIV-encoded mRNAs have been shown to be susceptible to RNAi down-regulation in cell lines, including tat, rev, gag, pol, nef, vif, env, vpr, and the LTR (Rossi et al. 2007).

A substantial challenge for clinical applications of RNAi inhibitors is the high mutation rate of HIV, which readily generates escape mutants. Ideally, conserved sequences on transcripts encoding gene products required for critical functions in the viral life cycle and that cannot tolerate mutations will need to be targeted (Zhang et al. 2007). An alternative approach to relying solely on RNAi is to combine a single shRNA with other antiviral genes, thereby providing synergistic inhibition. This approach has been successfully performed by coexpressing an anti-tat/rev shRNA, a nucleolar localizing TAR decoy, and an anti-CCR5 ribozyme in a single vector backbone ( $\mathrm{Li}$ et al. 2005). A pilot trial testing this triple combination lentiviral vector transduced into stem cells from patients with HIV and non-Hodgkin's lymphoma was recently reported (DiGiusto et al. 2010). Engraftment occurred by $11 \mathrm{~d}$, with low but persisting levels of gene marking observed in several cell lineages for up to 24 mo. In preclinical studies, this triple combination vector was compared to the protein-based maC46 fusion inhibitor and to a long RNA antisense vector, and was found to be less efficient than C46 in providing a selective advantage in HIV-1-infected cultures of primary $\mathrm{T}$ cells (Kimpel et al. 2010).

\section{CCR5 AS AN ANTI-HIV TARGET AND ERADICATION STRATEGIES}

The identification of CCR5 as the major coreceptor for transmitted HIV-1 isolates provided an explanation for the previously noted resistance of individuals who were frequently exposed to HIV, but remained uninfected, and were found to be homozygous for the CCR5 32 allele (Samson et al. 1996). The mutation is caused by a 32-bp deletion resulting in a frameshift mutation that truncates CCR5 and prevents its expression on the cell surface (Huang et al. 1996; Samson et al. 1996; Zimmerman et al. 1997). Given that individuals lacking CCR5 are entirely healthy, this observation provided a strong impetus for the development of drugs that target the virus-CCR5 interaction, one of which is now FDA approved (Gulick et al. 2008).

\section{The "Berlin Patient"}

Although CCR5 small molecule inhibitors are proving to be clinically useful (Gulick et al. 2008), their activity did not predict the remarkable outcome of a patient who has apparently 
been cured of HIV infection following an allogeneic HSC transplant from a homozygous CCR5 $\Delta 32$ donor in an extraordinary experiment conducted by Gero Hütter and colleagues in Berlin (Hütter et al. 2009). The patient, infected with HIV for 10 years and well controlled on antiretroviral therapy (ART), developed acute myelogenous leukemia unrelated to his HIV. When ART was interrupted during antileukemia chemotherapy, HIV plasma RNA not surprisingly increased to a high level, and was again controlled when ART was restarted. Despite achieving a remission, the patient's leukemia relapsed, requiring that an allogeneic HSC transplant be performed as lifesaving therapy. In the German database for unrelated donors, one individual was identified who was MHC compatible and also homozygous for the CCR5 32 mutation in CCR5. The patient received a HSC transplant from this donor, with ART being discontinued at the time of stem cell infusion. Strikingly, 31/2 years posttransplant and in the continued absence of antiretroviral therapy, no HIV has been detected using the most sensitive molecular assays for viral RNA or DNA in plasma, lymphoid tissues, and peripheral blood CD4 cells (Allers et al. 2010; Hutter and Thiel 2011). For a variety of reasons, including the low frequency of CCR5 $\Delta 32$ homozygotes in the general population and the logistics and feasibility of identifying suitable donors, similar transplants in HIV-infected patients are unlikely to be performed anytime soon, leaving open many questions (discussed further below) as to how HIV was eradicated in this patient (Deeks and McCune 2010). However, given this proof of concept that HIV infection can be apparently cured, the challenge to the field is to develop more generally applicable approaches that (1) do not require intensive myeloablative chemotherapy and (2) can be performed using autologous rather than allogeneic cells.

\section{HIV Latency}

The establishment of HIV latency and the failure of antiviral therapies to eradicate persisting, long-lived viral reservoirs is a central issue in the field (discussed by Siliciano and Greene 2011). Whereas the clinical result from the Berlin patient suggests that donor CCR5-negative HSCs and engraftment of HIV-resistant T cells can ultimately suppress or prevent HIV replication and eradicate HIV reservoirs, other mechanisms likely contributed (Deeks and McCune 2010; Cannon and June 2011). It is possible or even likely that the myeloablative therapy could have provided a synergistic effect. However, there are numerous reports of HIV-infected individuals undergoing allogeneic HSC or bone marrow transplants from donors not selected to be CCR5-negative, demonstrating that HIV-1 was not eliminated by the particular chemotherapy regimens used (Hassett et al. 1983; Angelucci et al. 1990; Bardini et al. 1991; Schlegel et al. 2000; Kang et al. 2002; Avettand-Fenoel et al. 2007; Wolf et al. 2007; Woolfrey et al. 2008; Kamp et al. 2010; Polizzotto et al. 2010), with one possible exception (Holland et al. 1989). Of note, the Berlin patient's myeloablative therapy consisted of amsacrine, fludarabine, cytarabine, and cyclophosphamide, a regimen that has not previously been reported in patients with HIV infection. He was also treated with total body irradiation (TBI), both to enhance the antileukemic chemotherapy and for immunosuppression to facilitate engraftment; although historically, TBI used in conjunction with myeloblative therapy has not eradicated HIV (Giri et al. 1992; Tomonari et al. 2005; Polizzotto et al. 2010). Of potential importance, the Berlin patient was also treated with several agents to prevent graft versus host disease, including antithymocyte globulin (ATG), cyclosporine, and mycophenolate mofetil, all of which have potent cytolytic or suppressive effects on T cells. Given the role of CD4/CCR5 memory T cells as a long-lived reservoir for HIV (Han et al. 2007), it is likely that these agents directly targeted this reservoir. ATG, in particular, is not only a potent immunosuppressive drug, but contains polyclonal antibodies directed against all known lymphocyte subsets (Rebellato et al. 1994). The effects of ATG in the setting are largely unknown, because this potent immunosuppressive agent has only rarely been given to 
patients with chronic HIV-1 infection (Wolf et al. 2007). Finally, it is possible that innate or acquired immunity delivered by the donor immune system may have contributed to the elimination of residual HIV reservoirs. The Berlin patient developed graft versus host disease, and an allogeneic immune response directed against host lymphocytes could have had a purging effect on latent HIV reservoirs. Allogeneic immune effects are among the most powerful known immune responses, and are capable of eradicating host lymphocytes and stem cells as well as malignant hematopoetic cells in the recipient (Barrett and Malkovska 1996; McSweeney et al. 2001). In summary, although an allogeneic transplant from a normal donor cannot in itself explain the remarkable clinical outcome reported by Hütter and colleagues, it is possible that transplantation with HIV-resistant cells, myeloablative therapy, anti-T-cell therapy, and alloimmune responses could all have contributed to the observed long-term control of HIV (Hütter et al. 2009; Allers et al. 2010; Hutter and Thiel 2011).

\section{GENE THERAPY STRATEGIES TO REDUCE CCR5 EXPRESSION}

As noted previously, there are a number of gene therapy approaches to inhibit CCR5 expression with a goal of mimicking the CCR5 null phenotype of a ccr5 532 homozygote (Nazari and Joshi 2008). These can act at the RNA level with RNA interference (Anderson et al. 2003; Qin et al. 2003; Anderson and Akkina 2005) or ribozymes (Bai et al. 2000, 2001; Cordelier et al. 2004), or at the protein level with CCR5-targeted intrabodies (Cordelier et al. 2004; Swan et al. 2006) or intrakines (Yang et al. 1997; Schroers et al. 2002). Improvements in humanized mouse models that support the generation of human $\mathrm{T}$ cells in vivo (Denton and Garcia 2009) are permitting analyses of their relative efficacies. Recent reports have highlighted the potential of RNA interference to down-regulate CCR5 expression, including the possibility of exploiting in vivo delivery of siRNAs through the use of T-cell-targeted nanoparticles (Kumar et al. 2008; Kim et al. 2009). Alternatively, RNA interference can be achieved through the stable expression of shRNAs targeting CCR5 from lentiviral vectors. Transduction of such vectors into human CD $34^{+}$HSC allowed HIV resistance to be conferred on both macrophages derived in vitro from the transduced cells (Liang et al. 2010) as well as T-cell progeny that differentiated in vivo in a bone marrow/liver/thymus (BLT) mouse model (Shimizu et al. 2010). A targeted strategy to deliver lentiviral vectors expressing an anti-CCR5 shRNA specifically to CCR5 ${ }^{+}$ cells in vivo was also shown using a PBMC transplanted mouse (Anderson et al. 2009) and in nonhuman primates after stem cell transplants (An et al. 2007).

Aside from these encouraging results in humanized mouse and nonhuman primate models, the utility of genetic approaches to treat HIV infection will ultimately require evaluation in patients. Given the chronic but typically manageable nature of HIV infection with ART, the clinical and ethical criteria for patient selection in gene therapy trials will need to be carefully considered. Notably, patients who develop AIDS-related malignancies, particularly lymphomas, a subset of which will require autologous HSC transplants, represent a unique cohort in which gene therapy approaches can be evaluated, because their HSCs are mobilized and harvested before chemotherapy. This provides both an opportunity to engineer HSCs to be resistant to HIV infection and to increase the chances of engraftment of the modified cells following a myeloablative conditioning regimen (DiGiusto et al. 2010). Moreover, as noted above, anti-lymphoma chemotherapy in this setting may have the added benefit of targeting HIV reservoirs.

\section{GENE-EDITING STRATEGIES TO DISRUPT CCR5}

All of the strategies described above have the challenge of achieving and maintaining sufficient levels of anti-CCR5 activity to decrease CCR5 expression to levels that are insufficient for HIV infection. In addition, in the case of 
Novel Cell and Gene Therapies for HIV

lentiviral vector-based approaches, there remains the theoretical risk of these integrating vectors causing insertional mutagenesis in host DNA. More recently, gene-editing approaches to achieve permanent CCR5 gene disruption have been described using ZFNs that do not require continuous expression of a therapeutic gene.

ZFNs are engineered fusion proteins that contain two linked domains: a DNA-binding zinc finger protein and the endonuclease domain of a type-1 restriction enzyme (Fig. 1) (Urnov et al. 2010). ZFNs have been designed to target many genes, including CCR5 and CXCR4, and are currently being evaluated in preclinical and clinical settings as HIV therapeutics (Lombardo et al. 2007; Perez et al. 2008; Holt et al. 2010; Wilen et al. 2011). The zinc finger protein domain is an artificial array of zinc finger peptides that confer sequence-specific
DNA-binding properties. This occurs because three to four residues toward the tip of each zinc finger peptide make contact with three or four base pairs of DNA. Altering the contact residues changes the specificity of the zinc finger for a DNA sequence. Moreover, linking multiple zinc fingers extends the length of the DNA sequence that is recognized, and because ZFNs are dimerized via their endonuclease domain, this further extends the length and the specificity of a targeted sequence. In this way, a ZFN pair engineered to bind to the sense and the antisense regions of a gene can target a sequence that is theoretically unique in the human genome, although the potential for off-target effects is always a consideration.

On binding, ZFNs act as designer restriction enzymes, cutting both strands of DNA at the bound target sequence. Following cleavage, the double-stranded break is repaired in

A
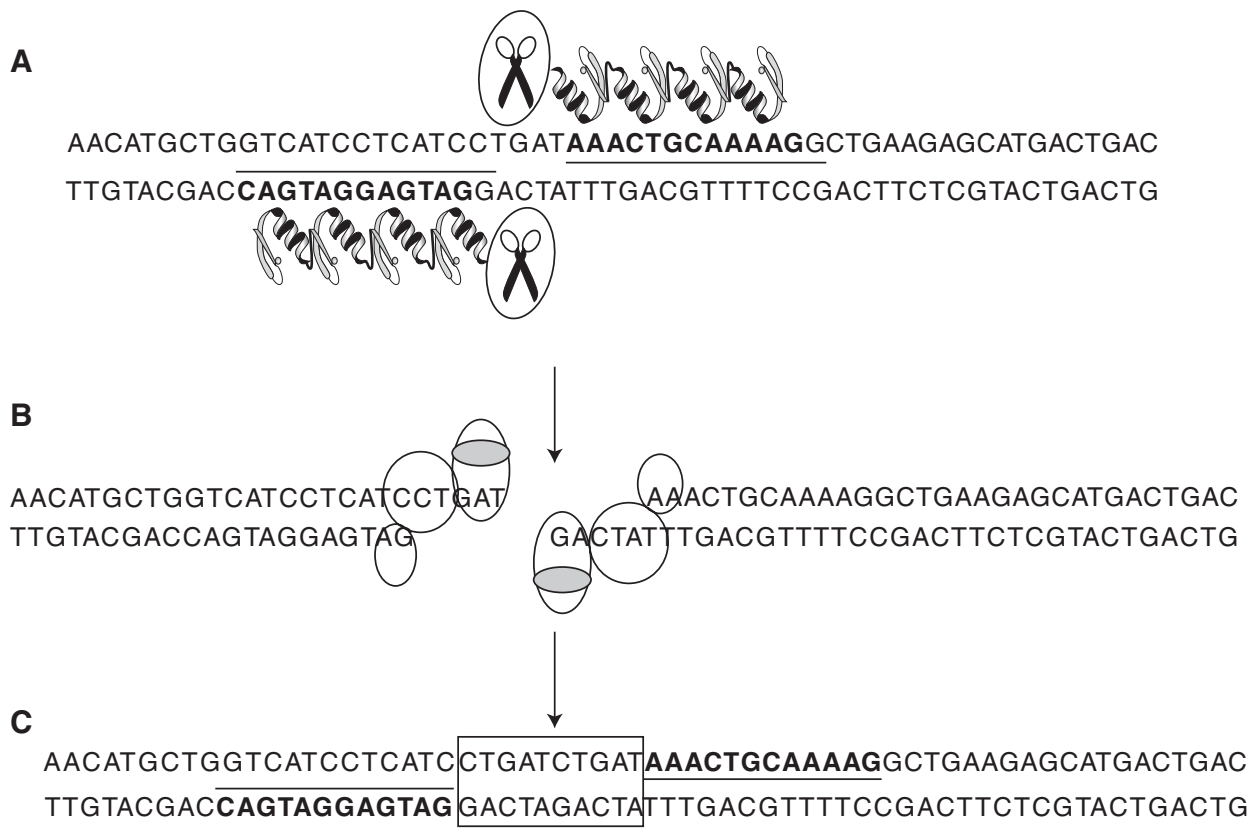

- Asn Met Leu Val Ile Leu lle Leu Ile * *

Figure 1. Zinc finger nucleases. (A) ZFNs bind CCR5 target sequence (underlined), and create a five-base-pair double-stranded staggered cut. $(B)$ The double-stranded break is repaired by the error-prone nonhomologous end-joining (NHEJ) repair pathway. $(C)$ The NHEJ results in a variety of insertions or deletions that disrupt the open reading frame (ORF). In the case of the CCR5 ZFNs, the most common repair leads to a 5-pb duplication (boxed). This insertion introduces two adjacent stop codons in the ORF that result in premature termination. (Figure adapted from Cannon and June 2011; reprinted, with permission, from the author.) 
mammalian cells, predominantly by the errorprone nonhomologous end-joining (NHEJ) pathway, which typically generates a series of small deletions or additions at the break site with disruption of the open reading frame (ORF). ZFNs that target the coding sequence for the CCR5 amino terminus have been described (Perez et al. 2008) in which a 5-bp duplication at the target site is commonly observed (Perez et al. 2008; Holt et al. 2010). This insertion changes the translational reading frame and so introduces two adjacent stop codons that result in premature termination (Fig. 1).

A key feature of ZFN gene editing is that the ZFNs are only required to be expressed during a short time window; once the double-stranded break is created, the host NHEJ repair pathway creates a permanent gene knockout that is propagated with cell division. ZFNs can be delivered to a wide variety of human cells using standard gene delivery techniques. Notably, vectors that transiently express ZFNs are effective and may even be preferable because they eliminate the risk of immunogenicity that is inherent in protein-based gene therapy approaches. Vectors currently in use include adenoviral and nonintegrating lentiviral vectors. Nucleofection of plasmid DNA or in vitrotranscribed mRNA has also been used successfully, albeit with less efficiency (Lombardo et al. 2007; Perez et al. 2008; Holt et al. 2010).

ZFNs can be directed to the mature target cells that HIV-1 infects, or HSCs that give rise to these cells. Delivery of ZFNs to peripheral $T$ cells has been especially effective using adenovirus vectors. In preclinical studies, Perez and colleagues (Perez et al. 2008) reported that adenovirus vector delivery of a CCR5-targeted ZFN pair led to disruption of $\sim 50 \%$ of CCR 5 alleles in populations of primary human $\mathrm{CD}^{+} \mathrm{T}$ cells. They further showed that the ZFN treatment generated HIV-resistant primary $\mathrm{CD}^{+}{ }^{+} \mathrm{T}$ cells that expanded stably in HIV-infected cultures for several weeks, resulting in enrichment of ZFN-generated CCR5modified cells in the population on long-term exposure to virus $(>50 \mathrm{~d})$. In addition, when the cells were transplanted into an immunodeficient NOD/LtSz-scid IL2R $\lambda$ null (NSG) mouse and followed by infection with a CCR5-tropic strain of HIV-1, the ZFN-modified $\mathrm{T}$ cells preferentially expanded, so that the proportion of modified cells present at the end of the experiment was greater than twoto threefold higher in the HIV-infected mice. Thus, a major finding from this work was that HIV infection itself can play an important role in selecting CCR5-negative cells. Even when present at low frequency, these cells are able to replenish and stabilize $\mathrm{T}$-cell populations, whereas nonedited CCR5 ${ }^{+}$cells are destroyed by HIV.

Disrupting the CCR5 gene in HSCs could create a more potent antiviral effect than in peripheral $\mathrm{T}$ cells, given the added advantage that CCR5-negative cells would be generated in all hematopoietic lineages that HIV-1 infects, including macrophages as well as T cells. However, manipulating HSCs is technically challenging, as these cells are difficult to maintain in culture without losing viability or undergoing differentiation. An additional problem is that CCR5 is not expressed in HSCs, and therefore it is not possible to positively select for CCR5-disrupted cells. An early report described using nonintegrating lentiviral vectors to deliver ZFNs to CD34 ${ }^{+}$HSCs, but the efficiency was poor (Lombardo et al. 2007). However, Holt and colleagues recently showed that nucleofection of human HSCs with ZFN plasmid DNA was particularly effective with an average disruption rate of $17 \%$ of CCR5 alleles (Holt et al. 2010). Importantly, these ZFN-modified cells retained their "stemness" and were subsequently able to engraft NSG mice with the same efficiency as were nonmodified HSCs. In addition, the frequency of CCR5-disrupted genes in HSCs before engraftment was maintained in mature cells following differentiation in vivo and persisted through a secondary transplantation, clearly indicating that in SCID mice the ZFNs were able to modify HSCs and that these cells retained the capacity to regenerate all hematopoietic lineages. Moreover, similar to the study of Perez and colleagues, when mice transplanted with ZFN-modified HSCs were challenged with a 
CCR5-tropic strain of HIV-1, CD4 cells that persisted in gut mucosa showed a potent selection for CCR5-negative, ZFN-modified cells (Holt et al. 2010).

\section{CLINICAL TRIALS TESTING CELL AND GENE TRANSFER APPROACHES FOR CHRONIC HIV INFECTION}

Cell-delivered gene therapy for HIV/AIDS has the potential to generate an immune system that is resistant to HIV that could theoretically contribute to the eradication of HIV reservoirs. As described in earlier sections, anti-HIV gene(s) can be introduced into HSC and/or T lymphocytes to provide a population of cells that is protected. Both HSC- and T-cell-directed approaches have shown promise. Although the potential benefits of HSC are substantial, there are two major challenges. First, the efficiencies of gene transfer with HSCs have been lower than with T-cell-directed therapies (Rossi et al. 2007; June et al. 2009), particularly regarding the ability to genetically modify long-term repopulating cells. Second, HSC appear to be more susceptible than mature $\mathrm{T}$ cells to genotoxicity from integrating viral vectors (Newrzela et al. 2008; Montini et al. 2009; Matrai et al. 2010). In contrast to the challenges in evaluating efficacy of anti-HIV gene therapy in HSCs, an attractive feature of gene therapy in T cells is that it is straightforward to determine therapeutic effects. Supervised treatment interruptions, if carefully performed, are safe and can provide definitive information on the antiviral efficacy of the vector by measuring changes in viral load or CD4 cell counts after the interruption. Recently, a subpopulation of postthymic $\mathrm{T}$ cells with extensive self-renewal capacity has been described (Zhang et al. 2005; Stemberger et al. 2007; Turtle et al. 2009), and it is possible that the generation of populations of autologous, HIV-resistant HSCs and T cells will be an efficient approach to replicate the encouraging findings with allogeneic HSC using CCR5 32 donor cells.

Avariety of the anti-HIV strategies discussed above has been tested in tissue culture and in animal models, and some have progressed to clinical trials (Table 1). The first direct test of the safety and feasibility of CCR 5 knockout T cells is currently being evaluated in a phase I clinical trial sponsored by Sangamo Biosciences (California), in conjunction with investigators at the University of Pennsylvania. Details of the protocol design can be found at clinicaltrials.gov NCT00842634. An overview of the clinical trial is shown in Figure 2.

\section{CONCLUDING REMARKS: TOWARD HIV ERADICATION}

Combination ART has dramatically improved the survival of patients with HIV infection and reduced the frequency of opportunistic infections and cancers. However, its use can be associated with significant long-term toxicities, and persisting inflammation and immune activation even in the face ART can impact clinical outcomes and survival (Butler et al. 2011). In addition, even with improvements in pharmacologic formulations of anti-HIV drugs, HIV infection continues to represent a significant economic burden, with the discounted, lifetime medical care cost of HIV-1 infection in the United States estimated at \$303,100 (2005 dollars) per person with $73 \%$ of this cost attributed to ARV drugs (Schackman et al. 2006). These realities provide an additional rationale for developing eradication therapies with the goal of long-term, drug-free control of HIV-1, a concept that before the Berlin patient, was unthinkable. As described in this review, the toolbox of strategies to render hematopoietic and lymphoid systems resistant to HIV infection continues to expand and to improve. Key challenges facing this emerging field are numerous and include the development of robust assays to measure the impact of therapies on latent HIV-1 reservoirs. Another issue is whether pleuripotent stem cells or progenitor cells constitute a potential reservoir, as suggested by a recent study (Carter et al. 2010). If confirmed, this study has major implications for therapies that contemplate the use of genemodified HSCs. Another barrier to implementing gene modification strategies is a possible requirement for myeloablative therapy to 


\section{$\$_{\mathrm{CSH}}^{\infty}$ Cold Spring Harbor Perspectives in Medicine

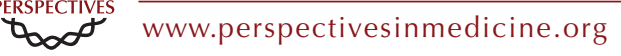

Table 1. Completed and ongoing cell and gene transfer trials for HIV

\begin{tabular}{|c|c|c|c|c|c|c|}
\hline Protocol description & Phase & Status & Payload & Cellular vehicle & Transfer vector & Reference(s) \\
\hline $\mathrm{T}$ cells & & & & & & \\
\hline $\begin{array}{l}\text { A randomized study of HIV-specific } \\
\text { T-cell gene therapy in subjects with } \\
\text { undetectable plasma viremia on }\end{array}$ & 2 & Completed & $\begin{array}{l}\text { CD4 receptor coupled with the } \\
\text { CD3 signaling chain } \zeta\end{array}$ & $\begin{array}{l}\text { Autologous } \mathrm{CD}^{+} \\
\text {and } \mathrm{CD} 8^{+} \mathrm{T} \text { cells; } \\
\text { (3) repeat doses }\end{array}$ & Murine retrovirus & Deeks et al. 2002 \\
\hline
\end{tabular}

1 Completed CD4 receptor coupled with the Syngeneic $\mathrm{CD}^{+}$or Murine retrovirus Walker et al. 2000

Evaluation of safety, tolerability, and persistence of escalating and repeat doses of genetically modified syngeneic $\mathrm{CD} 8^{+}$or $\mathrm{CD} 4^{+} / \mathrm{CD} 8^{+}$cells

Evaluation of safety, tolerability, and tissue trafficking of a single dose of genetically modified autologous $\mathrm{CD} 4^{+}$ and $\mathrm{CD}^{+}$cells

A clinical trial of $\mathrm{CD} 4 \zeta$ gene-modified T-cell infusion with and without IL-2 in HIV-infected participants

CD3 signaling chain $\zeta$ $\mathrm{CD} 4^{+} / \mathrm{CD}^{+}$cells single or multiple doses

1 Completed CD4 receptor coupled with the Autologous CD4 ${ }^{+}$ $\mathrm{CD} 3$ signaling chain $\zeta \quad$ and $\mathrm{CD} 8^{+}$cells;

$1 / 2$ Completed CD4 receptor coupled with the Autologous CD4 $\zeta$ CD3 signaling chain $\zeta \quad$ cells, randomized

Evaluation of safety and tolerability of a single infusion of autologous $\mathrm{CD} 4^{+} \mathrm{T}$ cells modified with a dominant negative anti-HIV gene

Evaluation of safety and tolerability of a single infusion of autologous retrovirally modified $\mathrm{CD}^{+}{ }^{+} \mathrm{T}$ cells to express a dominant negative anti-HIV gene

A marker study of therapeutically transduced $\mathrm{CD}^{+}$peripheral blood lymphocytes in HIV discordant identical twins

\section{Completed Rev M10}

1 Completed Rev M10
Completed Anti-HIV-1 tat ribozyme (Rz2) Syngeneic CD4 ${ }^{+}$ cells; single dose single dose comparison to cells only or IL-2 only

Murine retrovirus Mitsuyasu et al. 2000

Murine retrovirus Aronson et al. 2008 Autologous CD $4^{+}$ cells; single dose

Gold particles $\quad$ Woffendin et al. 1996

Autologous CD4 ${ }^{+}$ cells; single dose

Murine retrovirus Ranga et al. 1998

Murine retrovirus Macpherson et al. 2005 


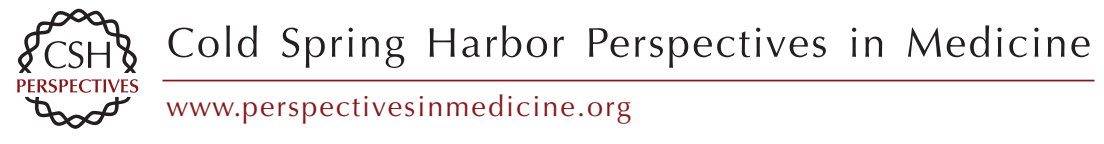

Evaluation of safety and tolerability of multiple infusions of syngeneic $\mathrm{CD} 4^{+}$ lymphocytes modified with anti-HIV genes

Evaluation of safety and tolerability of ribozyme gene therapy of HIV-1 infection

Evaluation of safety and tolerability of a single dose of autologous T cells transduced with VRX496 in

HIV-positive patient subjects

Evaluation of safety, tolerability, and antiviral effects of autologous $\mathrm{CD} 4^{+} \mathrm{T}$ cells expressing the HIV fusion inhibitor M87

An open-label, multicenter study to evaluate the safety, tolerability, and biological activity of repeated doses of autologous T cells transduced with VRX496 in HIV-positive subjects

An open-label, single center study to evaluate the tolerability, trafficking, and therapeutic effects of repeated doses of autologous $\mathrm{T}$ cells transduced with VRX496 in HIV-infected subjects Autologous T cells genetically modified at the CCR5 gene by zinc finger nucleases SB-728 for HIV (zinc-finger)

Study of autologous $\mathrm{T}$ cells genetically modified at the CCR5 gene by zinc finger nucleases

Phase 1 dose escalation study of autologous $\mathrm{T}$ cells genetically modified at the CCR5 gene by zinc finger nucleases in HIV-infected patients trans-dominant rev with TAR cells; two doses antisense

1 Completed Anti-HIV-1 ribozyme to the U5 Autologous CD4 ${ }^{+}$ leader sequence and pol cells; single dose

1 Completed Anti-HIV-1 antisense against the envelope gene

Completed gp41 fusion peptide inhibitor

Ongoing

Anti-HIV-1 antisense against the envelope gene (VRX496) the envelope gene (VRX496)

$$
\begin{aligned}
& \text { cells; }(4 \text { or } 8) \\
& \text { repeat doses }
\end{aligned}
$$

Autologous $\mathrm{CD}^{+}{ }^{+} \mathrm{T} \quad$ HIV-derived cells; (6) repeat lentivirus,

\section{Ongoing}

CCR5 modfied T cells (SB 728 T)

1/2 Ongoing CCR5-modfied T cells (SB 728 T)

$1 \quad$ Ongoing

$$
\text { T) }
$$
lentivirus, conditionally replicating doses conditionally replicating

Murine retrovirus Morgan et al. 2005

Murine retrovirus Wong-Staal et al. 1998

lenterived
conditions,
replicating

Levine et al. 2006$$
\text { et al. } 2006
$$

van Lunzen et al. 2007 cells

ClinicalTrials.gov NCT00131560

Collman et al. 2009; ClinicalTrials.gov NCT00295477

ClinicalTrials.gov NCT00842634 cells

ClinicalTrials.gov NCT01252641 cells

ClinicalTrials.gov NCT01044654 


\section{$\$_{\mathrm{CSH}}^{\infty}$ Cold Spring Harbor Perspectives in Medicine \\ PERSPCTIVES www.perspectivesinmedicine.org}

Table 1. Continued

\begin{tabular}{|c|c|c|c|c|c|c|}
\hline Protocol description & Phase & Status & Payload & Cellular vehicle & Transfer vector & Reference(s) \\
\hline $\begin{array}{l}\text { Redirected high-affinity gag-specific } \\
\text { autologous T cells for HIV gene } \\
\text { therapy }\end{array}$ & 1 & Ongoing & $\begin{array}{l}\text { HLA-A2 gag-specific CTLs } \\
\text { (wild-type and high-affinity } \\
\text { TCR) }\end{array}$ & $\begin{array}{l}\text { Autologous } \mathrm{CD}^{+} \mathrm{T} \\
\text { cells }\end{array}$ & $\begin{array}{l}\text { HIV-derived SIN } \\
\text { lentivirus }\end{array}$ & $\begin{array}{r}\text { ClinicalTrials.gov } \\
\text { NCT00991224 }\end{array}$ \\
\hline \multicolumn{7}{|l|}{ HSCs } \\
\hline $\begin{array}{l}\text { Nonmyeloablative conditioning followed } \\
\text { by transplantation of genetically } \\
\text { modified HLA-matched peripheral } \\
\text { blood progenitor cells for hematologic } \\
\text { malignancies in patients with AIDS }\end{array}$ & 1 & Completed & Trans-dominant Rev & $\begin{array}{l}\text { Autologous } \mathrm{CD} 34^{+} \\
\text {cells isolated from } \\
\text { mobilized } \\
\text { peripheral blood }\end{array}$ & Murine retrovirus & $\begin{array}{l}\text { Kang et al. 2002; } \\
\text { Hayakawa et al. } 2009\end{array}$ \\
\hline $\begin{array}{l}\text { Evaluation of retroviral-mediated } \\
\text { transfer of a rev-responsive element } \\
\text { decoy gene into CD } 34^{+} \text {cells from the } \\
\text { bone marrow of HIV-1-infected } \\
\text { children }\end{array}$ & 1 & Completed & RRE-decoy & $\begin{array}{l}\text { Autologous CD34 } \\
\text { bone marrow cells }\end{array}$ & Murine retrovirus & Kohn et al. 1999 \\
\hline $\begin{array}{l}\text { Evaluation of safety, tolerability, and } \\
\text { persistence of transplantation with }\end{array}$ & 1 & Completed & Dominant negative RevM10 & $\begin{array}{l}\text { Autologous CD34 } \\
\text { bone marrow cells }\end{array}$ & Murine retrovirus & Podsakoff et al. 2005 \\
\hline
\end{tabular}

autologous bone marrow transduced

bone marrow cells

with a retroviral vector expressing

dominant negative Rev or a control

gene 


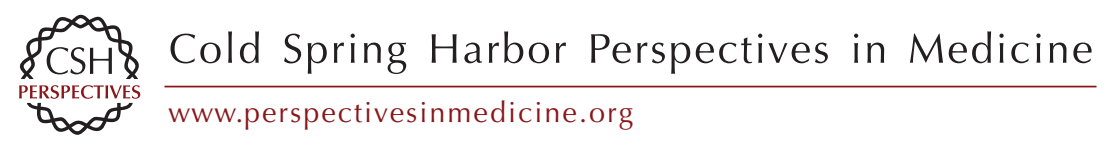

Tat and tat/rev ribozyme in autologous $\mathrm{CD} 34^{+}$cells and control vector in

patients with and without ablation

Evaluation of safety and tolerability of autologous $\mathrm{CD} 34^{+}$hematopoietic

progenitor cells transduced with an anti-HIV ribozyme

A randomized, double-blind, controlled trial to evaluate the safety and efficacy of autologous $\mathrm{CD} 34^{+}$hematopoietic progenitor cells transduced with placebo or an anti-HIV-1 ribozyme (OZ1) in patients with HIV-1

infection

A pilot study of safety and feasibility of stem cell therapy for AIDS lymphoma using stem cells treated with a lentivirus vector encoding multiple anti-HIV RNAs
1 Completed Rev/tat ribozyme

1 Completed Anti-HIV-1 tat ribozyme (Rz2)

2 Completed Anti-HIV ribozyme OZ-1

\author{
Autologous CD34 $4^{+}$ \\ bone marrow cells \\ Murine retrovirus Michienzi et al. 2003; \\ Look for Rossi \\ Murine retrovirus Amado et al. 1999, \\ 2004 \\ cells isolated from \\ mobilized \\ peripheral blood \\ Autologous CD34 ${ }^{+} \quad$ Murine retrovirus Mitsuyasu et al. 2009
} cells isolated from mobilized

peripheral blood

1 Completed Triple combination vector coexpressing an anti-tat/rev

Autologous CD34 ${ }^{+}$HIV-derived lentivirus

DiGiusto et al. 2010

TAR decoy, and an

anti-CCR5 ribozyme in a

single vector backbone

CCR5 knockout in autologous T cells can be achieved by infection with an Ad5/35 vector (SB-728) expressing left and right ZFNs, linked by a self-cleaving protease $2 \mathrm{~A}$ sequence. In an ongoing phase I clinical trial, the CCR5-modified T cells are expanded ex vivo using antibodies to CD3 and CD28 for $\sim 10$ days and adoptively transferred to the patient. The study end points are listed.

TAR, trans-activation response; TCR, T-cell receptor; RRE, Rev response element. 
J.A. Hoxie and C.H. June
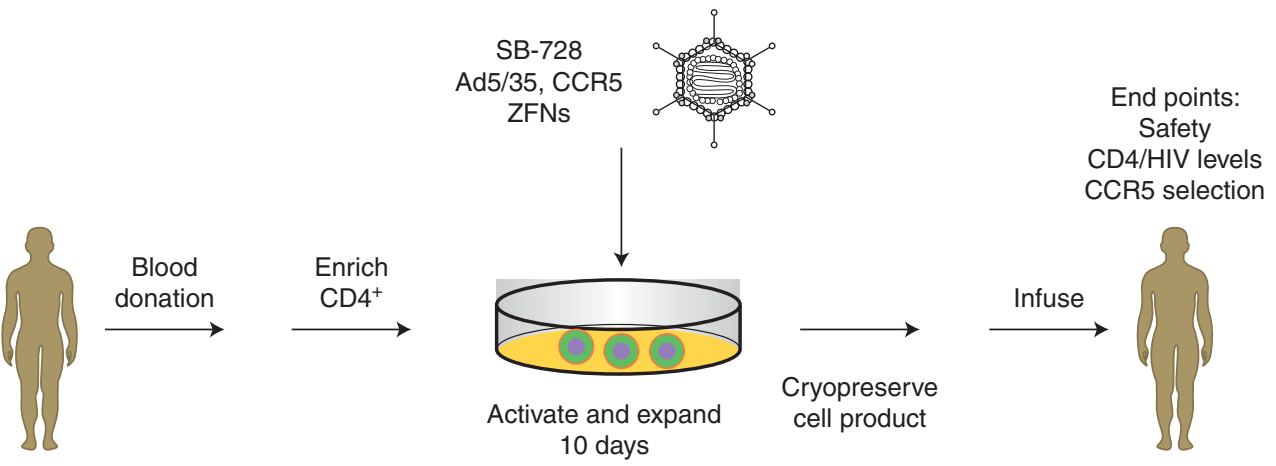

Figure 2. First clinical application of CCR5 ZFNs ( protocol NCT00842634; see text).

facilitate engraftment of gene-modified HSCs. However, there is progress in the area of inducible selection systems for HSCs, for example, using modified methylguanine methyltransferase (Milsom and Williams 2007; Trobridge et al. 2009; Beard et al. 2010), and if proven safe, these approaches may circumvent this issue. Given the remarkable proof of concept that HIV infection can be eradicated (Hütter et al. 2009; Allers et al. 2010; Hutter and Thiel 2011), this field will be an exciting one for renewed research efforts.

\section{REFERENCES}

${ }^{*}$ Reference is also in this collection.

Allers K, Hütter G, Hofmann J, Loddenkemper C, Rieger K, Thiel E, Schneider T. 2010. Evidence for the cure of HIV infection by CCR $5 \Delta 32 / \Delta 32$ stem cell transplantation. Blood 117: 2791-2799.

Amado RG, Mitsuyasu RT, Symonds G, Rosenblatt JD, Zack J, Sun LQ, Miller M, Ely J, Gerlach W. 1999. A phase I tria of autologous $\mathrm{CD} 34^{+}$hematopoietic progenitor cells transduced with an anti-HIV ribozyme. Human Gene Ther 10: 2255-2270.

Amado RG, Mitsuyasu RT, Rosenblatt JD, Ngok FK, Bakker A, Cole S, Chorn N, Lin LS, Bristol G, Boyd MP, et al. 2004. Anti-human immunodeficiency virus hematopoietic progenitor cell-delivered ribozyme in a phase I study: Myeloid and lymphoid reconstitution in human immunodeficiency virus type-1-infected patients. Hum Gene Ther 15: 251-262.

An DS, Donahue RE, Kamata M, Poon B, Metzger M, Mao SH, Bonifacino A, Krouse AE, Darlix JL, Baltimore D, et al. 2007. Stable reduction of CCR5 by RNAi through hematopoietic stem cell transplant in non-human primates. Proc Natl Acad Sci 104: 13110-13115.

Anderson WF. 1984. Prospects for human gene therapy. Science 226: 401-409.
Anderson J, Akkina R. 2005. HIV-1 resistance conferred by siRNA cosuppression of CXCR 4 and CCR 5 coreceptors by a bispecific lentiviral vector. AIDS Res Theory 2: 1-12.

Anderson J, Banerjea A, Akkina R. 2003. Bispecific short hairpin siRNA constructs targeted to CD4, CXCR4, and CCR5 confer HIV-1 resistance. Oligonucleotides 13: 303-312.

Anderson JS, Walker J, Nolta JA, Bauer G. 2009. Specific transduction of HIV-susceptible cells for CCR5 knockdown and resistance to HIV infection: A novel method for targeted gene therapy and intracellular immunization. J Acquir Immune Defic Syndr 52: 152-161.

Angelucci E, Lucarelli G, Baronciani D, Durazzi SM, Galimberti M, Maddaloni D, Polchi P. 1990. Bone marrow transplantation in an HIV positive thalassemic child following therapy with azidothymidine. Haematologica 75 : 285-287.

Aronson N, Benstein W, Levine B, Jagodzinski L, Plesa G, Cox J, Darden J, Polonis V, Gibbs B, Flaks H, et al. 2008. A clinical trial of CD4 $\zeta$ gene-modified T cell infusion with and without IL-2 in HIV-infected participants. In AIDS 2008 XVII International AIDS Conference, 3-8 August 2008, Abstract TUPDA104, p. 328. Mexico City.

Arya SK, Guo C, Josephs SF, Wong-Staal F. 1985. Transactivator gene of human T-lymphotropic virus type III (HTLV-III). Science 229: 69.

Avettand-Fenoel V, Mahlaoui N, Chaix ML, Milliancourt C, Burgard M, Cavazzana-Calvo M, Rouzioux C, Blanche S. 2007. Failure of bone marrow transplantation to eradicate HIV reservoir despite efficient HAART. AIDS 21: 776-777.

Bai J, Gorantla S, Banda N, Cagnon L, Rossi J, Akkina R. 2000. Characterization of anti-CCR5 ribozyme-transduced $\mathrm{CD} 34^{+}$hematopoietic progenitor cells in vitro and in a SCID-hu mouse model in vivo. Mol Ther 1: 244-254.

Bai J, Rossi J, Akkina R. 2001. Multivalent anti-CCR5 ribozymes for stem cell-based HIV type 1 gene therapy. AIDS Res Hum Retrov 17: 385-399.

Baker JV, Peng G, Rapkin J, Abrams DI, Silverberg MJ, MacArthur RD, Cavert WP, Henry WK, Neaton JD Terry Beirn Community Programs for Clinical Research on AIDS (CPCRA). 2008. $\mathrm{CD}^{+}$count and risk of 
non-AIDS diseases following initial treatment for HIV infection. AIDS 22: 841-848.

Baltimore D. 1988. Gene therapy. Intracellular immunization. Nature 335: 395-396.

Bardini G, Re MC, Rosti G, Belardinelli AR. 1991. HIV infection and bone-marrow transplantation. Lancet 337: 1163-1164.

Barrett A, Malkovska V. 1996. Graft-versus-leukaemia: Understanding and using the alloimmune response to treat haematological malignancies. Brit J Haematol 93: 754-761.

Bauer G, Valdez P, Kearns K, Bahner I, Wen SF, Zaia JA, Kohn DB. 1997. Inhibition of human immunodeficiency virus-1 (HIV-1) replication after transduction of granulocyte colony-stimulating factor-mobilized $\mathrm{CD} 34^{+}$cells from HIV-1-infected donors using retroviral vectors containing anti-HIV-1 genes. Blood 89: 2259-2267.

Beard BC, Trobridge GD, Ironside C, McCune JS, Adair JE, Kiem HP. 2010. Efficient and stable MGMT-mediated selection of long-term repopulating stem cells in nonhuman primates. J Clin Invest 120: 2345-2354.

Blankson JN, Persaud D, Siliciano RF. 2002. The challenge of viral reservoirs in HIV-1 infection. Annu Rev Med 53: 557-593.

Bohjanen PR, Liu Y, Garcia-Blanco MA. 1997. TAR RNA decoys inhibit tat-activated HIV-1 transcription after preinitiation complex formation. Nucleic Acids Res 25: 4481-4486.

Butler SL, Valdez H, Westby M, Perros M, June CH, Jacobson JM, Levy Y, Cooper DA, Douek D, Lederman MM, Tebas P. 2011. Disease-modifying therapeutic concepts for HIV in the era of highly active antiretroviral therapy. $J$ Acquir Immune Defic Syndr (in press).

Cannon P, June C. 2011. Chemokine receptor 5 knockout strategies. Curr Opin HIVAIDS 6: 74-79.

Carter CC, Onafuwa-Nuga A, McNamara LA, Riddell JIV, Bixby D, Savona MR, Collins KL. 2010. HIV-1 infects multipotent progenitor cells causing cell death and establishing latent cellular reservoirs. Nat Med 16: 446-451.

Cavazzana-Calvo M, Fischer A. 2007. Gene therapy for severe combined immunodeficiency: Are we there yet? J Clin Invest 117: 1456- 1465.

Chatterjee S, Johnson PR, Wong KKJr. 1992. Dual-target inhibition of HIV-1 in vitro by means of an adeno-associated virus antisense vector. Science 258: 1485-1488.

Cheung MC, Pantanowitz L, Dezube BJ. 2005. AIDS-related malignancies: Emerging challenges in the era of highly active antiretroviral therapy. Oncologist 10: 412.

Chun TW, Fauci AS. 1999. Latent reservoirs of HIV: Obstacles to the eradication of virus. Proc Natl Acad Sci 96: $10958-10961$.

Collman R, Shaheen F, Boyer J, Binder G, Zifchak L, Aberra F, McGarrity G, Levine B, Tebas P, June C, et al. 2009. Safety, antiviral effects, and quantitative measurement of modified CD4 T cells trafficking to gut lymphoid tissue in a phase I/II open-label clinical trial evaluating multiple infusions of lentiviral vector-modified CD4 T cells expressing long env antisense. In 16th Conference on Retroviruses and Opportunistic Infections Abstract \#83, Feb 9, 2009. Montreal, Canada.
Cordelier P, Kulkowsky JW, Ko C, Matskevitch AA, McKee HJ, Rossi JJ, Bouhamdan M, Pomerantz RJ, Kari G, Strayer DS. 2004. Protecting from R5-tropic HIV: Individual and combined effectiveness of a hammerhead ribozyme and a single-chain Fv antibody that targets CCR5. Gene Ther 11: 1627-1637.

Deeks SG, McCune JM. 2010. Can HIV be cured with stem cell therapy? Nat Biotechnol 28: 807-810.

Deeks SG, Wagner B, Anton PA, Mitsuyasu RT, Scadden DT, Huang C, Macken C, Richman DD, Christopherson C, June $\mathrm{CH}$, et al. 2002. A phase II randomized study of HIV-specific T-cell gene therapy in subjects with undetectable plasma viremia on combination anti-retroviral therapy. Mol Ther 5: 788-797.

Denton P, Garcia J. 2009. Novel humanized murine models for HIV research. Curr HIV/AIDS Rep 6: 13-19.

DiGiusto DL, Krishnan A, Li L, Li H, Li S, Rao A, Mi S, Yam P, Stinson S, Kalos M, et al. 2010. RNA-based gene therapy for HIV with Lentiviral vector-modified CD34 ${ }^{+}$ cells in patients undergoing transplantation for AIDSrelated lymphoma. Sci Transl Med 2: 36-43.

Dropulic B, June CH. 2006. Gene-based immunotherapy for human immunodeficiency virus infection and acquired immunodeficiency syndrome. Hum Gene Ther 17: $577-588$.

Dropulić B, Heermánková M, Pitha PM. 1996. A conditionally replicating HIV-1 vector interferes with wild-type HIV-1 replication and spread. Proc Natl Acad Sci 93: 11103-11108.

Edelstein ML, Abedi MR, Wixon J. 2007. Gene therapy clinical trials worldwide to 2007-An update. J Gene Med 9: $833-842$.

Egelhofer M, Brandenburg G, Martinius H, Schult-Dietrich P, Melikyan G, Kunert R, Baum C, Choi I, Alexandrov A, von Laer D, et al. 2004. Inhibition of human immunodeficiency virus type 1 entry in cells expressing gp41derived peptides. J Virol 78: 568-575.

Friedmann T. 1992. A brief history of gene therapy. Nat Genet 2: 93-98.

Friedmann T, Roblin R. 1972. Gene therapy for human genetic disease? Science 175: 949-955.

Geng EH, Deeks SG. 2009. CD4 ${ }^{+}$T cell recovery with antiretroviral therapy: More than the sum of the parts. Clin Infect Dis 48: 362-364.

Giorgi JV, Hultin LE, McKeating JA, Johnson TD, Owens B, Jacobson LP, Shih R, Lewis J, Wiley DJ, Phair JP, et al. 1999. Shorter survival in advanced human immunodeficiency virus type 1 infection is more closely associated with $\mathrm{T}$ lymphocyte activation than with plasma virus burden or virus chemokine coreceptor usage. J Infect Dis 179: $859-870$.

Giri N, Vowels MR, Ziegler JB. 1992. Failure of allogeneic bone marrow transplantation to benefit HIV infection. J Paediatr Child Health 28: 331-333.

Gulick RM, Lalezari J, Goodrich J, Clumeck N, DeJesus E, Horban A, Nadler J, Clotet B, Karlsson A, Wohlfeiler M, et al. 2008. Maraviroc for previously treated patients with R5 HIV-1 infection. N Engl J Med 359: 1429-1441.

Han Y, Wind-Rotolo M, Yang HC, Siliciano JD, Siliciano RF 2007. Experimental approaches to the study of HIV-1 latency. Nat Rev Microbiol 5: 95-106. 
J.A. Hoxie and C.H. June

Hannon G, Rossi J. 2004. Unlocking the potential of the human genome with RNA interference. Nature 431: 371-378.

Hassett J, Zaroulis C, Greenberg ML, Siegal FP, et al. 1983. Bone-marrow transplantation in AIDS. $N$ Engl J Med 309: $665-665$.

Hayakawa J, Washington K, Uchida N, Phang O, Kang EM, Hsieh MM, Tisdale JF. 2009. Long-term vector integration site analysis following retroviral mediated gene transfer to hematopoietic stem cells for the treatment of HIV infection. PLoS One 4: e4211. doi: 10.1371/ journal.pone.0004211.

Held DM, Kissel JD, Patterson JT, Nickens DG, Burke DH. 2006. HIV-1 inactivation by nucleic acid aptamers. Front Biosci 11: 89-112.

Held DM, Kissel JD, Thacker SJ, Michalowski D, Saran D, Ji J, Hardy RW, Rossi JJ, Burke DH. 2007. Cross-clade inhibition of recombinant human immunodeficiency virus type 1 (HIV-1), HIV-2, and simian immunodeficiency virus SIVcpz reverse transcriptases by RNA pseudoknot aptamers. J Virol 81: 5375-5384.

Hildinger M, Dittmar MT, Schult-Dietrich P, Fehse B, Schnierle BS, Thaler S, Stiegler G, Welker R, von Laer D. 2001. Membrane-anchored peptide inhibits human immunodeficiency virus entry. J Virol 75: 3038-3042.

Holland HK, Saral R, Rossi JJ, Donnenberg AD, Burns WH, Beschorner WE, Farzadegan H, Jones RJ, Quinnan GV, Vogelsang GB. 1989. Allogeneic bone marrow transplantation, zidovudine, and human immunodeficiency virus type 1 (HIV-1) infection. Studies in a patient with nonHodgkin lymphoma. Ann Intern Med 111: 973-981.

Holt N, Wang J, Kim K, Friedman G, Wang X, Taupin V, Crooks GM, Kohn DB, Gregory PD, Holmes MC, et al. 2010. Human hematopoietic stem/progenitor cells modified by zinc-finger nucleases targeted to CCR 5 control HIV-1 in vivo. NatBiotechnol 28: 839-847.

Huang Y, Paxton WA, Wolinsky SM, Neumann AU, Zhang L, He T, Kang S, Ceradini D, Jin Z, Yazdanbakhsh K, et al. 1996. The role of a mutant CCR5 allele in HIV-1 transmission and disease progression. Nat Med 2: 1240-1243.

Hutter G, Thiel E. 2011. Allogeneic transplantation of CCR5-deficient progenitor cells in a patient with HIV infection: An update after 3 years and the search for patient no. 2. AIDS 25: 273-274.

Hütter G, Nowak D, Mossner M, Ganepola S, Müssig A, Allers K, Schneider T, Hofmann J, Kücherer C, Blau O, et al. 2009. Long-term control of HIV by CCR5 $\Delta 32$ / $\Delta 32$ stem-cell transplantation. $N$ Engl J Med 360: $692-$ 696.

Joshi PJ, Fisher TS, Prasad VR. 2003. Anti-HIV inhibitors based on nucleic acids: Emergence of aptamers as potent antivirals. Curr Drug Targets Infect Disord 3: 383-400.

June CH, Blazar BR, Riley JL. 2009. Engineering lymphocyte subsets: Tools, trials and tribulations. Nat Rev Immunol 9: 704-716.

Kamp C, Wolf T, Bravo IG, Kraus B, Krause B, Neumann B, Winskowsky G, Thielen A, Werner A, Schnierle BS. 2010. Decreased HIV diversity after allogeneic stem cell transplantation of an HIV-1 infected patient: A case report. Virol J 7: 55.

Kang EM, de Witte M, Malech H, Morgan RA, Phang S, Carter C, Leitman SF, Childs R, Barrett AJ, Little R, et al.
2002. Nonmyeloablative conditioning followed by transplantation of genetically modified HLA-matched peripheral blood progenitor cells for hematologic malignancies in patients with acquired immunodeficiency syndrome. Blood 99: 698-701.

Kaufmann GR, Zaunders JJ, Cunningham P, Kelleher AD, Grey P, Smith D, Carr A, Cooper DA. 2000. Rapid restoration of $\mathrm{CD} 4 \mathrm{~T}$ cell subsets in subjects receiving antiretroviral therapy during primary HIV-1 infection. AIDS 14: $2643-2651$.

Kelley CF, Kitchen CM, Hunt PW, Rodriguez B, Hecht FM, Kitahata M, Crane HM, Willig J, Mugavero M, Saag M, et al. 2009. Incomplete peripheral $\mathrm{CD}^{+}$cell count restoration in HIV-infected patients receiving long-term antiretroviral treatment. Clin Infect Dis 48: 787-794.

Kim SS, Peer D, Kumar P, Subramanya S, Wu H, Asthana D, Habiro K, Yang YG, Manjunath N, Shimaoka M, et al. 2009. RNAi-mediated CCR5 silencing by LFA-1-targeted nanoparticles prevents HIV infection in BLT mice. Mol Ther 18: 370-376.

Kimpel J, Braun SE, Qiu G, Wong FE, Conolle M, Schmitz JE, Brendel C, Humeau LM, Dropulic B, Rossi JJ, et al. 2010. Survival of the fittest: Positive selection of $\mathrm{CD}^{+}$ $\mathrm{T}$ cells expressing a membrane-bound fusion inhibitor following HIV-1 infection. PLoS One 5: 378-384.

Kissel JD, Held DM, Hardy RW, Burke DH. 2007. Active site binding and sequence requirements for inhibition of HIV-1 reverse transcriptase by the RT1 family of single-stranded DNA aptamers. Nucleic Acids Res 35: 5039-5050.

Kitahata MM, Gange SJ, Abraham AG, Merriman B, Saag MS, Justice AC, Hogg RS, Deeks SG, Eron JJ, Brooks JT, et al. 2009. Effect of early versus deferred antiretroviral therapy for HIV on survival. $N$ Engl J Med 360: $1815-1826$.

Kohn DB, Bauer G, Rice CR, Rothschild JC, Carbonaro DA, Valdez P, Hao Q, Zhou C, Bahner I, Kearns K, et al. 1999. A clinical trial of retroviral-mediated transfer of a rev-responsive element decoy gene into $\mathrm{CD} 34^{+}$cells from the bone marrow of human immunodeficiency virus-1-infected children. Blood 94: 368-371.

Kumar P, Ban HS, Kim SS, Wu H, Pearson T, Greiner DL, Laouar A, Yao J, Haridas V, Habiro K, et al. 2008. T cellspecific siRNA delivery suppresses HIV-1 infection in humanized mice. Cell 134: 577-586.

Lane HC, Masur H, Longo DL, Klein HG, Rook AH, Quinnan GVJr, Steis RG, Macher A, Whalen G, Edgar LC. 1984. Partial immune reconstitution in a patient with the acquired immunodeficiency syndrome. $N$ Engl J Med 311: 1099-1103.

Lares MR, Rossi JJ, Ouellet DL. 2010. RNAi and small interfering RNAs in human disease therapeutic applications. Trends Biotechnol 28: 570-579.

Leavitt MC, Yu M, Yamada O, Kraus G, Looney D, Poeschla E, Wong-Staal F. 1994. Transfer of an anti-HIV-1 ribozyme gene into primary human lymphocytes. Hum Gene Ther 5: 1115-1120.

Lee SW, Gallardo HF, Gilboa E, Smith C. 1994. Inhibition of human immunodeficiency virus type 1 in human T cells by a potent Rev response element decoy consisting of the 13-nucleotide minimal Rev-binding domain. J Virol 68: $8254-8264$ 
Lee NS, Dohjima T, Bauer G, Li H, Li MJ, Ehsani A, Salvaterra P, Rossi J. 2002. Expression of small interfering RNAs targeted against HIV-1 rev transcripts in human cells. Nat Biotechnol 20: 500-505.

Lekakis J, Ikonomidis I. 2010. Cardiovascular complications of AIDS. Curr Opin Crit Care 16: 408-412.

Levine BL, Humeau LM, Boyer J, MacGregor RR, Rebello T, Lu X, Binder GK, Slepushkin V, Lemiale F, Mascola JR, et al. 2006. Gene transfer in humans using a conditionally replicating lentiviral vector. Proc Natl Acad Sci 103: 17372-17377.

Lewden C, Salmon D, Morlat P, Bévilacqua S, Jougla E, Bonnet F, Héripret L, Costagliola D, May T, Chêne G. Mortality 2000 Study Group. 2005. Causes of death among human immunodeficiency virus (HIV)-infected adults in the era of potent antiretroviral therapy: emerging role of hepatitis and cancers, persistent role of AIDS. Int J Epidemiol 34: 121-130.

Lewden C, Chene G, Morlat P, Raffi F, Dupon M, Dellamonica P, Pellegrin JL, Katlama C, Dabis F, Leport C, Agence Nationale de Recherches sur le Sida et les Hepatites Virales. 2007. HIV-infected adults with a CD4 cell count greater than 500 cells $/ \mathrm{mm}^{3}$ on long-term combination antiretroviral therapy reach same mortality rates as the general population. J Acquir Immune Defic Syndr 46: $72-77$.

Li MJ, Kim J, Li S, Zaia J, Yee JK, Anderson J, Akkina R, Rossi JJ. 2005. Long-term inhibition of HIV-1 infection in primary hematopoietic cells by lentiviral vector delivery of a triple combination of anti-HIV shRNA, anti-CCR5 ribozyme, and a nucleolar-localizing TAR decoy. Mol Ther 12: 900-909.

Liang M, Kamata M, Chen KN, Pariente N, An DS, Chen IS. 2010. Inhibition of HIV-1 infection by a unique short hairpin RNA to chemokine receptor 5 delivered into macrophages through hematopoietic progenitor cell transduction. J Gene Med 12: 255-265.

Lisziewicz J, Sun D, Smythe J, Lusso P, Lori F, Louie A, Markham P, Rossi J, Reitz M, Gallo RC. 1993. Inhibition of human immunodeficiency virus type 1 replication by regulated expression of a polymeric Tat activation response RNA decoy as a strategy for gene therapy in AIDS. Proc Natl Acad Sci 90: 8000-8004.

Lo AS, Zhu Q, Marasco WA. 2008. Intracellular antibodies (intrabodies) and their therapeutic potential. In Therapeutic antibodies (ed. Chernajovsky Y, Nissim A), Vol. 181, pp. 343-373. Springer-Verlag, Berlin.

Lobato M, Rabbitts T. 2004. Intracellular antibodies as specific reagents for functional ablation: Future therapeutic molecules. Curr Mol Med 4: 519-528.

Lohse N, Hansen AB, Pedersen G, Kronborg G, Gerstoft J, Sørensen HT, Vaeth M, Obel N. 2007. Survival of persons with and without HIV infection in Denmark, 19952005. Ann Intern Med 146: 87-95.

Lombardo A, Genovese P, Beausejour CM, Colleoni S, Lee YL, Kim KA, Ando D, Urnov FD, Galli C, Gregory PD, et al. 2007. Gene editing in human stem cells using zinc finger nucleases and integrase-defective lentiviral vector delivery. Nat Biotechnol 25: 1298-1306.

Lu X, Yu Q, Binder GK, Chen Z, Slepushkina T, Rossi J, Dropulic B. 2004. Antisense-mediated inhibition of human immunodeficiency virus (HIV) replication by use of an HIV type 1-based vector results in severely attenuated mutants incapable of developing resistance. $J$ Virol 78: 7079-7088.

Maartens G, Boulle A, Mocroft A, Phillips AN, Gatell J, Ledergerber B, Fisher M, Clumeck N, Losso M, Lazzarin A, et al. 2007. Normalisation of CD4 counts in patients with HIV-1 infection and maximum virological suppression who are taking combination antiretroviral therapy: An observational cohort study. Commentary. Lancet 370: $407-413$.

Macpherson JL, Boyd MP, Arndt AJ, Todd AV, Fanning GC, Ely JA, Elliott F, Knop A, Raponi M, Murray J, et al. 2005. Long-term survival and concomitant gene expression of ribozyme-transduced $\mathrm{CD}^{+}{ }^{+} \mathrm{T}$-lymphocytes in HIV-infected patients. J.Gene Med 7: 552-564.

* Malim MH, Bieniasz PD. 2011. HIV restriction factors and mechanisms of evasion. Cold Spring Harb Pespect Med doi: $10.1101 /$ cshperspect.a006940.

Malim MH, Freimuth WW, Liu J, Boyle TJ, Lyerly HK, Cullen BR, Nabel GJ, et al. 1992. Stable expression of transdominant Rev protein in human $\mathrm{T}$ cells inhibits human immunodeficiency virus replication. J Exp Med 176: $1197-1201$.

Mátrai JM, Chuah MK, VandenDriessche T. 2010. Recent advances in lentiviral vector development and applications. Mol Ther 18: 477-490.

McSweeney P, Niederwieser D, Shizuru JA, Sandmaier BM, Molina AJ, Maloney DG, Chauncey TR, Gooley TA, Hegenbart U, Nash RA, et al. 2001. Hematopoietic cell transplantation in older patients with hematologic malignancies: Replacing high-dose cytotoxic therapy with graft-versus-tumor effects. Blood 97: 3390-3400.

Michaels MG, Kaufman C, Volberding PA, Gupta P, Switzer WM, Heneine W, Sandstrom P, Kaplan L, Swift P, Damon L, et al. 2004. Baboon bone-marrow xenotransplant in a patient with advanced HIV disease: Case report and 8-year follow-up. Transplantation 78: 1582-1589.

Michienzi A, Castanotto D, Lee N, LI S, Zaia JA, Rossi JJ. 2003. RNA-mediated inhibition of HIV in a gene therapy setting. Ann NY Acad Sci 1002: 63-71.

Mitsuyasu R, Merigan T, Carr A, Zack JA, Winters MA, Workman C, Bloch M, Lalezari J, Becker S, Thornton L, et al. 2009. Phase 2 gene therapy trial of an anti-HIV ribozyme in autologous CD34 ${ }^{+}$cells. Nat Med 15: 285-292.

Milsom MD, Williams DA. 2007. Live and let die: In vivo selection of gene-modified hematopoietic stem cells via MGMT-mediated chemoprotection. DNA Repair 6: $1210-1221$.

Mitsuyasu RT, Anton PA, Deeks SG, Scadden DT, Connick E, Downs MT, Bakker A, Roberts MR, June CH, Jalali S, et al. 2000. Prolonged survival and tissue trafficking following adoptive transfer of $\mathrm{CD} 4 \zeta$ gene-modified autologous $\mathrm{CD}^{+}$and $\mathrm{CD} 8^{+} \mathrm{T}$ cells in human immunodeficiency virus-infected subjects. Blood 96: 785-793.

Montini E, Cesana D, Schmidt M, Sanvito F, Bartholomae CC, Ranzani M, Benedicenti F, Sergi Sergi L, Ambrosi A, Ponzoni M, et al. 2009. The genotoxic potential of retroviral vectors is strongly modulated by vector design and integration site selection in a mouse model of HSC gene therapy. J Clin Invest 119: 964-975.

Moore R, Keruly J, Gebo K, Lucas G. 2005. An improvement in virologic response to highly active antiretroviral 
J.A. Hoxie and C.H. June

therapy in clinical practice from 1996 through 2002. J Acquir Immune Defic Syndr 39: 195-198.

Morgan RA, Walker R, Carter CS, Natarajan V, Tavel JA, Bechtel C, Herpin B, Muul L, Zheng Z, Jagannatha S, et al. 2005. Preferential survival of $\mathrm{CD} 4^{+} \mathrm{T}$ lymphocytes engineered with anti-human immunodeficiency virus (HIV) genes in HIV-infected individuals. Hum Gene Ther 16: 1065-1074.

Nazari R, Joshi S. 2008. CCR5 as target for HIV-1 gene therapy. Curr Gene Ther 8: 264-272.

Newrzela S, Cornils K, Li Z, Baum C, Brugman MH, Hartmann M, Meyer J, Hartmann S, Hansmann ML, Fehse B, et al. 2008. Resistance of mature T cells to oncogene transformation. Blood 112: 2278-2286.

Ngok FK, Mitsuyasu RT, Macpherson JL, Boyd MP, Symonds GP, Amado RG. 2004. Clinical gene therapy research utilizing ribozymes: Application to the treatment of HIV/AIDS. Methods Mol Biol 252: 581-598.

Nimjee SM, Rusconi CP, Sullenger BA. 2005. Aptamers: An emerging class of therapeutics. Medicine 56: 555-583.

Nisole S, Stoye JP, Saïb A. 2005. TRIM family proteins: Retroviral restriction and antiviral defence. Nat Rev Microbiol 3: 799-808.

Nunez M. 2010. Clinical syndromes and consequences of antiretroviral-related hepatotoxicity. Hepatology 52: 1143-1155.

Perez EE, Riley JL, Carroll RG, von Laer D, June CH. 2005. Suppression of HIV-1 infection in primary CD4 T cells transduced with a self-inactivating lentiviral vector encoding a membrane expressed gp41-derived fusion inhibitor. Clin Immunol 115: 26-32.

Perez EE, Wang J, Miller JC, Jouvenot Y, Kim KA, Liu O, Wang N, Lee G, Bartsevich VV, Lee YL, et al. 2008. Establishment of HIV-1 resistance in $\mathrm{CD} 4^{+} \mathrm{T}$ cells by genome editing using zinc-finger nucleases. Nat Biotechnol 26: 808-816.

Podsakoff GM, Engel BC, Carbonaro DA, Choi C, Smogorzewska EM, Bauer G, Selander D, Csik S, Wilson K, Betts MR, et al. 2005. Selective survival of peripheral blood lymphocytes in children with HIV-1 following delivery of an anti-HIV gene to bone marrow $\mathrm{CD} 34^{+}$cells. Mol Ther 12: 77-86.

Polizzotto MN, Skinner M, Cole-Sinclair MF, Opat SS, Spencer A, Avery S. 2010. Allo-SCT for hematological malignancies in the setting of HIV. Bone Marrow Transpl 45: $584-586$.

Poluri A, van Maanen M, Sutton RE. 2003. Genetic therapy for HIV/AIDS. Expert Opin Biol Ther 3: 951-963.

Qin XF, An DS, Chen IS, Baltimore D. 2003. Inhibiting HIV-1 infection in human T cells by lentiviral-mediated delivery of small interfering RNA against CCR5. Proc Natl Acad Sci 100: 183-188.

Ranga U, Woffendin C, Verma S, Xu L, June CH, Bishop DK, Nabel GJ. 1998. Retroviral delivery of an antiviral gene in HIV-infected individuals. Proc Natl Acad Sci 95: 1201-1206.

Rebellato LM, Gross U, Verbanac KM, Thomas JM. 1994. A comprehensive definition of the major antibody specificities in polyclonal rabbit antithymocyte globulin. Transplantation 57: 685-694.
Richman DD, Margolis DM, Delaney M, Greene WC, Hazuda D, Pomerantz RJ. 2009. The challenge of finding a cure for HIV infection. Science 323: 1304-1307.

Rodger AJ, Fox Z, Lundgren JD, Kuller LH, Boesecke C, Gey D, Skoutelis A, Goetz MB, Phillips AN. INSIGHT Strategies for Management of Antiretroviral Therapy (SMART) Study Group. 2009. Activation and coagulation biomarkers are independent predictors for the development of opportunistic disease in patients with HIV infection. J Infect Dis 200: 973-983.

Rossi JJ, June CH, Kohn DB, et al. 2007. Genetic therapies for HIV/AIDS. Nat Biotechnol 25: 1444-1454.

Samson M, Libert F, Doranz BJ, Rucker J, Liesnard C, Farber CM, Saragosti S, Lapoumeroulie C, Cognaux J, Forceille C, et al. 1996. Resistance to HIV-1 infection in caucasian individuals bearing mutant alleles of the CCR- 5 chemokine receptor gene [see comments]. Nature 382: $722-725$.

Sarver N, Cantin EM, Chang PS, Zaia JA, Ladne PA, Stephens DA, Rossi JJ. 1990. Ribozymes as potential anti-HIV-1 therapeutic agents. Science 247: 1222-1225.

Schackman BR, Gebo KA, Walensky RP, Losina E, Muccio T, Sax PE, Weinstein MC, Seage GR III, Moore RD, Freedberg KA. 2006. The lifetime cost of current human immunodeficiency virus care in the United States. Med Care 44: 990-997.

Schlegel P, Beatty P, Halvorsen R, McCune J. 2000. Successful allogeneic bone marrow transplant in an HIV-1-positive man with chronic myelogenous leukemia. J Acquir Immune Defic Syndr 24: 289-290.

Schroers R, Davis CM, Wagner HJ, Chen SY. 2002. Lentiviral transduction of human T-lymphocytes with a RANTES intrakine inhibits human immunodeficiency virus type 1 infection. Gene Ther 9: 889-897.

Shimizu S, Hong P, Arumugam B, Pokomo L, Boyer J, Koizumi N, Kittipongdaja P, Chen A, Bristol G, Galic Z, et al 2010. A highly efficient short hairpin RNA potently down-regulates CCR5 expression in systemic lymphoid organs in the hu-BLT mouse model. Blood 115: 1534-1544.

* Siliciano RF, Greene WC. 2011. HIV latency. Cold Spring Harb Perspect Med doi: 10.1101/cshperspect.a007096.

Sodroski J, Rosen C, Goh WC, Haseltine W. 1985. A transcriptional activator protein encoded by the $\mathrm{x}$-lor region of the human T-cell leukemia virus. Science 228: 1430.

Stemberger C, Huster KM, Koffler M, Anderl F, Schiemann $\mathrm{M}$, Wagner H, Busch DH. 2007. A single naive $\mathrm{CD}^{+} \mathrm{T}$ cell precursor can develop into diverse effector and memory subsets. Immunity 27: 985-997.

Strayer DS, Akkina R, Bunnell BA, Dropulic B, Planelles V, Pomerantz RJ, Rossi JJ, Zaia JA. 2005. Current status of gene therapy strategies to treat HIV/AIDS. Mol Ther 11: $823-842$.

Stremlau M, Owens CM, Perron MJ, Kiessling M, Autissier P, Sodroski J. 2004. The cytoplasmic body component TRIM5 $\alpha$ restricts HIV- 1 infection in Old World monkeys. Nature 427: 848-853.

Stremlau M, Perron M, Lee M, Li Y, Song B, Javanbakht H, Diaz-Griffero F, Anderson DJ, Sundquist WI, Sodroski J. 2006. Specific recognition and accelerated uncoating of retroviral capsids by the TRIM5 $\alpha$ restriction factor. Proc Natl Acad Sci 103: 5514-5519. 
Swan CH, Bühler B, Steinberger P, Tschan MP, Barbas CF III, Torbett BE. 2006. T-cell protection and enrichment through lentiviral CCR5 intrabody gene delivery. Gene Ther 13: 1480-1492.

Symensma TL, Giver L, Zapp M, Takle GB, Ellington AD. 1996. RNA aptamers selected to bind human immunodeficiency virus type $1 \mathrm{Rev}$ in vitro are Rev responsive in vivo. J Virol 70: 179-187.

Tebas P, Stein D, Zifchak L, Seda A, Binder G, Aberra F, Collman R, McGarrity G, Levine B, June C, et al. 2010. Prolonged control of viremia after transfer of autologous CD4 T cells genetically modified with a lentiviral vector expressing long antisense to HIV env (VRX496). In 17th Conference of Retroviruses and Opportunistic Infections. San Francisco.

Tomonari A, Takahashi S, Shimohakamada Y, Ooi J, Takasugi K, Ohno N, Konuma T, Uchimaru K, Tojo A, Odawara T, et al. 2005. Unrelated cord blood transplantation for a human immunodeficiency virus-1-seropositive patient with acute lymphoblastic leukemia. Bone Marrow Transpl 36: 261-262.

Trobridge GD, Wu RA, Beard BC, Chiu SY, Muñoz NM, von Laer D, Rossi JJ, Kiem HP. 2009. Protection of stem cellderived lymphocytes in a primate AIDS gene therapy model after in vivo selection. PLoS One 4: e7693. doi: 10.1371/journal.pone.0007693.

Turtle CJ, Swanson HM, Fujii N, Estey EH, Riddell SR. 2009. A distinct subset of self-renewing human memory $\mathrm{CD} 8^{+}$ $\mathrm{T}$ cells survives cytotoxic chemotherapy. Immunity 31 834-844.

Urnov FD, Rebar EJ, Holmes MC, Zhang HS, Gregory PD. 2010. Genome editing with engineered zinc finger nucleases. Nat Rev Genet 11: 636-646.

Valdez H, Connick E, Smith KY, Lederman MM, Bosch RJ, Kim RS, St Clair M, Kuritzkes DR, Kessler H, Fox L, AIDS Clinical Trials Group Protocol 375 Team, et al. 2002. Limited immune restoration after 3 years' suppression of HIV-1 replication in patients with moderately advanced disease. AIDS 16: 1859-1866.

van Lunzen J, Glaunsinger T, Stahmer I, von Baehr V, Baum C, Schilz A, Kuehlcke K, Naundorf S, Martinius H, Hermann F, et al. 2007. Transfer of autologous gene-modified $\mathrm{T}$ cells in HIV-infected patients with advanced immunodeficiency and drug-resistant virus. Mol Ther 15: 1024-1033.

von Laer D, Hasselmann S, Hasselmann K.. 2006. Impact of gene-modified $\mathrm{T}$ cells on HIV infection dynamics. $J$ Theor Biol 238: 60-77.

Walker RE, Bechtel CM, Natarajan V, Baseler M, Hege KM Metcalf JA, Stevens R, Hazen A, Blaese RM, Chen CC, et al. 2000. Long-term in vivo survival of receptormodified syngeneic $\mathrm{T}$ cells in patients with human immunodeficiency virus infection. Blood 96: 467-474.

Wang GP, Levine BL, Binder GK, Berry CC, Malani N, McGarrity G, Tebas P, June CH, Bushman FD. 2009. Analysis of lentiviral vector integration in $\mathrm{HIV}^{+}$study subjects receiving autologous infusions of gene modified $\mathrm{CD} 4^{+} \mathrm{T}$ cells. Mol Ther 17: 844-850.

Wilen CB, Wang J, Tilton JC, Miller JC, Kim KA, Rebar EJ, Sherrill-Mix SA, Patro SC, Secreto AJ, Jordan AP, et al. 2011. Engineering HIV-resistant human $\mathrm{CD}^{+}{ }^{+} \mathrm{T}$ cells with CXCR4-specific zinc-finger nucleases. PLoS Pathog 7: e1002020. doi: 10.1371/journal.ppat.1002020.

Woffendin C, Ranga U, Yang Z, Xu L, Nabel GJ. 1996. Expression of a protective gene prolongs survival of $\mathrm{T}$ cells in human immunodeficiency virus-infected patients. Proc Natl Acad Sci 93: 2889-2894.

Wolf T, Rickerts V, Staszewski S, Kriener S, Wassmann B, Bug G, Bickel M, Gute P, Brodt HR, Martin H. 2007. First case of successful allogeneic stem cell transplantation in an HIV-patient who acquired severe aplastic anemia. Haematologica 92: e56-e58.

Wong-Staal F, Poeschla EM, Looney DJ. 1998. A controlled, phase 1 clinical trial to evaluate the safety and effects in HIV-1 infected humans of autologous lymphocytes transduced with a ribozyme that cleaves HIV-1 RNA. Hum Gene Ther 9: 2407-2425.

Woolfrey AE, Malhotra U, Harrington RD, McNevin J, Manley TJ, Riddell SR, Coombs RW, Appelbaum FR, Corey L, Storb R. 2008. Generation of HIV-1-specific $\mathrm{CD}^{+}$cell responses following allogeneic hematopoietic cell transplantation. Blood 112: 3484-3487.

Xia C, Luo D, Yu X, Jiang S, Liu S. 2011. HIV-associated dementia in the era of highly active antiretroviral therapy (HAART). Microbes Infect 13: 419-425.

Yang AG, Bai X, Huang XF, Yao C, Chen S. 1997. Phenotypic knockout of HIV type 1 chemokine coreceptor CCR- 5 by intrakines as potential therapeutic approach for HIV-1 infection. Proc Natl Acad Sci 94: 11567.

Yap MW, Nisole S, Stoye JP. 2005. A single amino acid change in the SPRY domain of human Trim5 aleads to HIV-1 restriction. Curr Biol 15: 73-78.

Zhang Y, Joe G, Hexner E, Zhu J, Emerson SG. 2005. Hostreactive $\mathrm{CD}^{+}$memory stem cells in graft-versus-host disease. Nat Med 11: 1299-1305.

Zhang J, Wu YO, Xiao L, Li K, Chen LL, Sirois P. 2007. Therapeutic potential of RNA interference against cellular targets of HIV infection. Mol Biotechnol 37: 225-236.

Zhang JC, Sun L, Nie QH, Huang CX, Jia ZS, Wang JP, Lian JQ, Li XH, Wang PZ, Zhang Y, et al. 2009. Downregulation of CXCR4 expression by SDF-KDEL in CD $34^{+}$hematopoietic stem cells: An anti-human immunodeficiency virus strategy. J Virol Methods 161: 30-37.

Zimmerman PA, Buckler-White A, Alkhatib G, Spalding T, Kubofcik J, Combadiere C, Weissman D, Cohen O, Rubbert A, Lam G, et al. 1997. Inherited resistance to HIV-1 conferred by an inactivating mutation in CC chemokine receptor 5: Studies in populations with contrasting clinical phenotypes, defined racial background, and quantified risk. Mol Med 3: 23-36. 


\section{$\&_{\mathrm{CSH}}^{\infty} \&$ Cold Spring Harbor

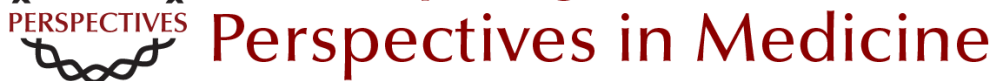

\section{Novel Cell and Gene Therapies for HIV}

James A. Hoxie and Carl $H$. June

Cold Spring Harb Perspect Med 2012; doi: 10.1101/cshperspect.a007179

\section{Subject Collection HIV}

HIV Pathogenesis: Dynamics and Genetics of

Viral Populations and Infected Cells John Coffin and Ronald Swanstrom

Human Immunodeficiency Virus Vaccine Trials Robert J. O'Connell, Jerome H. Kim, Lawrence Corey, et al.

HIV Transmission George M. Shaw and Eric Hunter

Novel Cell and Gene Therapies for HIV James A. Hoxie and Carl H. June

\section{Behavioral and Biomedical Combination}

Strategies for HIV Prevention Linda-Gail Bekker, Chris Beyrer and Thomas C. Quinn

HIV-1 Assembly, Budding, and Maturation Wesley I. Sundquist and Hans-Georg Kräusslich

HIV-1 Assembly, Budding, and Maturation Wesley I. Sundquist and Hans-Georg Kräusslich

Lessons in Nonhuman Primate Models for AIDS Vaccine Research: From Minefields to Milestones Jeffrey D. Lifson and Nancy L. Haigwood
HIV-1 Pathogenesis: The Virus Ronald Swanstrom and John Coffin

The T-Cell Response to HIV Bruce Walker and Andrew McMichael

HIV-1 Reverse Transcription Wei-Shau Hu and Stephen H. Hughes

HIV Pathogenesis: The Host A.A. Lackner, Michael M. Lederman and Benigno Rodriguez

HIV: Cell Binding and Entry Craig B. Wilen, John C. Tilton and Robert W. Doms

Innate Immune Control of HIV Mary Carrington and Galit Alter

HIV DNA Integration Robert Craigie and Frederic D. Bushman

HIV-1-Related Central Nervous System Disease: Current Issues in Pathogenesis, Diagnosis, and Treatment Serena Spudich and Francisco González-Scarano

For additional articles in this collection, see http://perspectivesinmedicine.cshlp.org/cgi/collection/ 